\section{Influence of Photoperiod on Liatris spicata Generative Shoot Growth}

\author{
Ignacio Espinosa'and Will Healy ${ }^{2}$ \\ Department of Horticulture, University of Maryland, College Park, \\ MD 20742
}

Additional index words. cut flower, pot plant, stem elongation, short days, facultative long-day plant

Abstract. One-year-old corms of Liatris spicata Willd. produced from seed and 2-yearold corms from division of previously forced corms were placed under 8 hours of natural daylight plus 0,4 , 6 , or 8 hours of incandescent $\left(5 \mu \mathrm{mol} \cdot \mathrm{s}^{-1} \cdot \mathrm{m}^{-2}\right)$ day continuation to equal 8-, 12-, or 16-hour photoperiods. Plants were grown under these photoperiods during the first 35 days after shoot emergence (initial) and then were grown under a second photoperiod of $8,12,14$, or 16 hours until harvest (final). The combination of initial and final photoperiod treatments resulted in a total of 16 photoperiod combinations. Two-year-old corms flowered 10 days earlier than l-year-old corms, but l-year-old corms produced twice as many vegetative shoots and $15 \%$ more flowering shoots than the 2-year-old corms. Long initial photoperiod (14 or 16 hours) treatments . (LD) reduced-the days to flower by 8 days and increased flower shoot elongation by $20 \mathrm{~cm}$, compared with initial short days (8 or 12 hours, SD). However, initial LD treatments decreased the number of flowering shoots by $50 \%$, compared to initial SD treatments. An initial SD followed by a final LD did not decrease the number of flowering shoots, yet promoted greater stem elongation $(92 \mathrm{~cm})$ than continuous LD $(83 \mathrm{~cm})$.

The effect of photoperiod on Liatris has been studied by various authors. Flowering in L. spicata was promoted by long days (LD) (Durieux, 1978), while L. graminifolia was described as a short-day (SD) plant (Allard and Garner, 1940). A LD treatment was not obligatory for flower initiation, but stem elongation (Durieux, 1978; Kofranek, 1980; Koziol et al., 1981; Zieslin and Geller, 1983) and stem rigidity (Zieslin and Geller, 1983) were promoted by LD.

Zieslin and Geller (1983) found that an 8hr photoperiod doubled the number of flower stems harvested compared to the 16-hr treatment. An 8-hr photoperiod for 3 weeks, followed by one of $16 \mathrm{hr}$ until anthesis, did not reduce the number of flowering stems. This result was in contrast to reports with gladiolus, where SD caused a low flowering percentage (Halevy, 1985; Shillo and Halevy, 1976). Long-day treatments provided by incandescent lamps promoted winter flowering of gladiolus in greenhouses (Halevy, 1985)

Received for publication 13 Aug. 1987. Scientific Article no. A-5011 of the Maryland Agricultural Experiment Station. The cost of publishing this paper was defrayed in part by the payment of page charges. Under postal regulations, this paper therefore must be hereby marked advertisement solely to indicate this fact.

'Graduate Student.

${ }^{2}$ Assistant Professor. and in fields in Israel (Shillo et al., 1981) and Australia (Mckay et al., 1982). In California, Kofranek (1980) recommended that Liatris be grown under LD (2200 to 0200 $\mathrm{HR})$ to promote stem elongation. This rec-

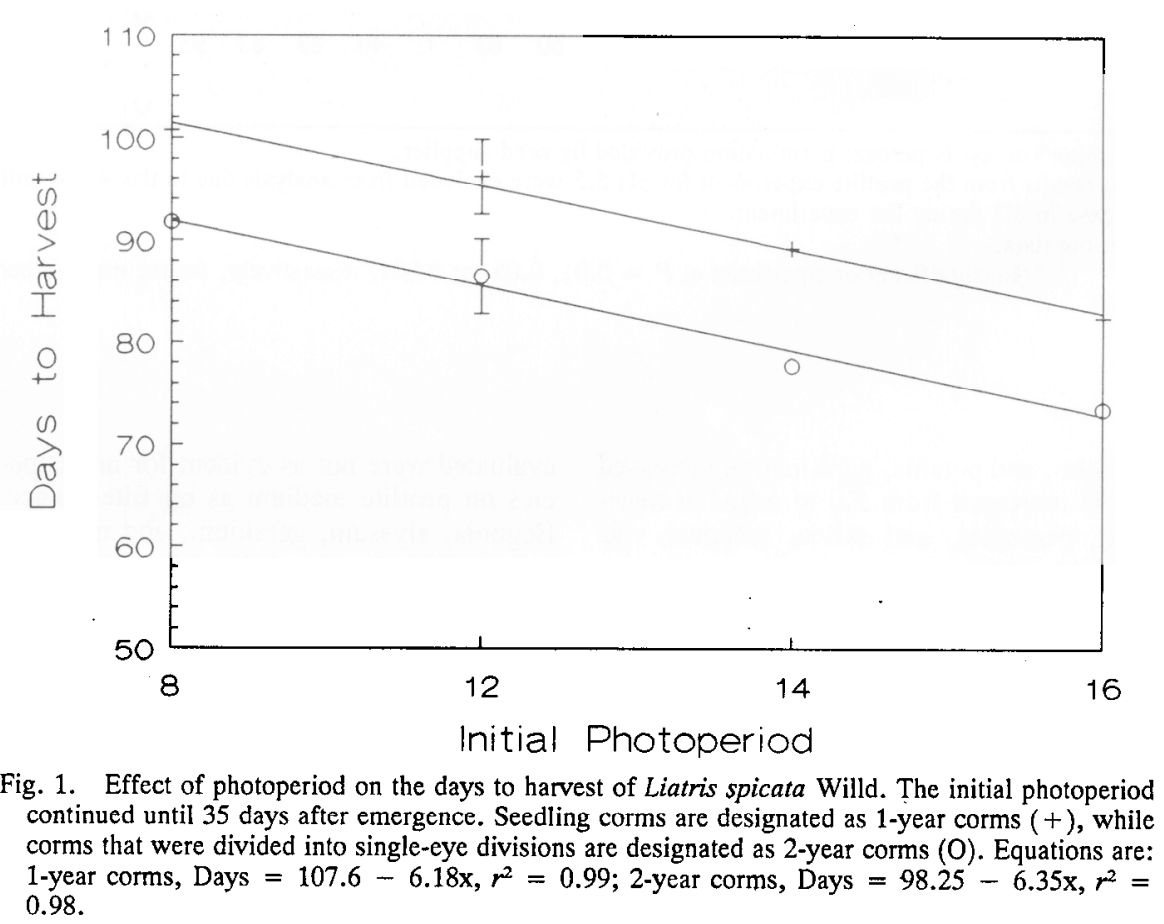

Fig. 1. Effect of photoperiod on the days to harvest of Liatris spicata Willd. The initial photoperiod continued until 35 days after emergence. Seedling corms are designated as 1-year corms $(+)$, while corms that were divided into single-eye divisions are designated as 2-year corms $(\mathrm{O})$. Equations are: 1 -year corms, Days $=107.6-6.18 \mathrm{x}, r^{2}=0.99 ; 2$-year corms, Days $=98.25-6.35 \mathrm{x}, r^{2}=$ 0.98 . moved to an 8-, 12-, 14-, or 16-hr photoperiod until harvest. This combination resulted in a total of 16 photoperiods. Each photoperiod treatment had 12 plants, each of 1- and 2-year-old corms. The experiment was ommendation seems to have been intuitive, as no data were presented to support this recommendation. Once the stem was elongated, flowering occurred more rapidly under natural winter SD conditions than under LD (Shillo and Halevy, 1976).

The objective of our research was to study the effect of photoperiod treatment and corm age during two developmental stages on generative shoot development of Liatris spicata.

One- and 2-year-old corms (2.5- to 3.5$\mathrm{cm}$ diameter) were used. One-year-old corms, produced in the Netherlands from seedlings, were cold-treated at $2 \mathrm{C}$ for 8 weeks, then stored at $-2 \mathrm{C}$ until used. The 2-year-old corms were obtained by division of corms forced in Maryland the first year, then coldtreated to break dormancy (12 weeks at $2.5 \mathrm{C}$ ). These corms were divided into single-bud corm divisions of uniform size. The corms were planted 24 Jan., one per 1.75-liter pot, and grown in a glasshouse at $18 \mathrm{C}$ night air temperature. Plants were fertilized weekly with $20 \mathrm{~N}-9 \mathrm{P}-16.6 \mathrm{~K}$ at $200 \mathrm{mg} / \mathrm{liter}$.

After emergence, photoperiod treatments of an 8-hr natural day plus a 0-, 4-, 6-, or 8-hr day continuation with incandescent irradiance $\left(5 \mu \mathrm{mol} \cdot \mathrm{s}^{-1} \cdot \mathrm{m}^{-2}\right)$ to equal 8 -, 12-, 14-, or 16-hr photoperiods were applied for 35 days. (initial). The plants were then 


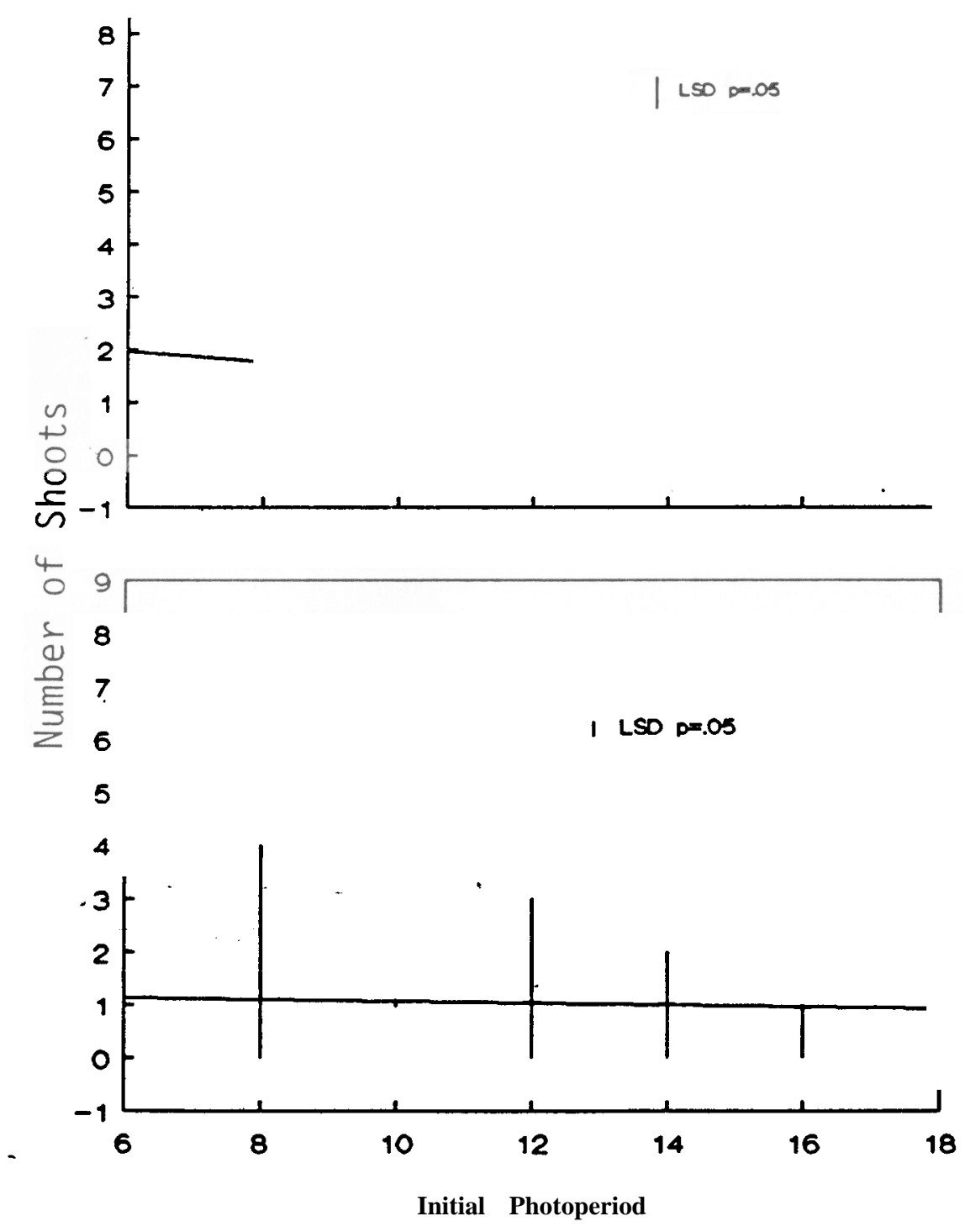

Fig. 2. Effect of corm age (1-year-old, top; 2-year-old, bottom) and initial photoperiod (during the first 35 days after emergence) on the number of generative shoots of Liatris spicata Willd. The bars represent the minimum and maximum number of generative shoots harvested under each photoperiod. Equations are: 1-year corms number of shoots $=2.55-0.096 \mathrm{x}, r^{2}=0.97 ; 2$-year corms number of shoots $=1.25-0.0175 \mathrm{x}, r^{2}=0.96$.

replicated in two separate glasshouses with a split-split-plot design with the whole plot as the initial photoperiod, the subplot the final photoperiod, and the sub-subplot the corm age.

Generative shoots were harvested when the apical $5 \mathrm{~cm}$ of flowers had opened. At harvest, the following variables were measured: number of vegetative and generative shoots per pot, generative shoot length, inflorescence length, and the days to harvest calculated from the day of emergence. Analysis of variance was used to determine treatment effects with mean separation by least significant difference, where $\mathrm{F}$ values were significant at $P=0.05$.

Days to harvest. Two-year-old corms flowered 10 days earlier than those 1 year old ( 92 vs. 82 days; sig. $P=0.05$ ). A linear relationship exists between days to harvest and photoperiod. As the length of the initial toperiod during both the initial and final reatment periods produced plants that were up to $20 \mathrm{~cm}$ shorter than those grown under a 14- or 16-hr photoperiod (Fig. 3). An 8or 12-hr final photoperiod reduced the promotive effect of an initial long photoperiod. Furthermore, plants that received an 8-hr then a 16-hr photoperiod produced a shoot $11 \mathrm{~cm}$ longer than did a continuous 16-hr photoperiod.

Percentage of shoot length bearing flowers. Due to the variation in shoot length and inflorescence length (data not presented), the percentage of shoot length bearing flowers was calculated to normalize the data. The 2year-old corms produced a slightly longer generative portion of stem length than did 1year-old corms (32\% vs. $29 \%$; $P=0.05$ ). As the initial photoperiod increased, the percentage of the shoot that bore flowers increased from $29 \%$ to $32 \%$, but the final photoperiod had no effect ( $30 \%$ to $31 \%$ ). In terms of inflorescence quality, this difference could be commercially important (Zieslin and Geller, 1983). The increase in percentage of the shoot length bearing flowers may be due to either an increase in internode length or number of flowers initiated.

The decrease in days to harvest observed with the 2-year-old corms could be due to a more-developed growing point at the time of planting or lack of competition from the other lateral buds. The latter observation is supported, by the relationship between the number of generative shoots and the days to harvest (Figs. 1, 2). The days to harvest decreased as the number of shoots decreased.

The effect of the photoperiod treatment on the days to flower occurs primarily during the first 35 days of growth (Fig. 1). Therefore, a grower may manipulate the photoperiod during this period to program the harvest date. This response may also explain the differences between results in Kenya and Europe; in Kenya, plants flower within 90 days year around, while in the Netherlands only 70 days are required during summer plantings (Durieux, 1978; Mevel, 1983). The natural photoperiod is up to $4 \mathrm{hr} 30 \mathrm{~min}$ longer in the Netherlands (16 hr $44 \mathrm{~min})$ than in Kenya (12 hr $11 \mathrm{~min}$ ) during the summer season. When summer twilight is taken into consideration, plants in the Netherlands perceive constant twilight, whereas plants in Kenya perceive only $1 \mathrm{hr} 15 \mathrm{~min}$ of twilight. Data presented in this study (Fig. 1) by Mevel (1983) and by Zieslin and Geller (1983) clearly show that Liatris spicata is a facultative long-day plant.

The number of vegetative shoots and the number of flowering shoots produced were related to corm age and photoperiod (Fig. 2 ). This response could have been predetermined by the division method of the 2-yearold corms that allowed for selection of single buds, which was not the case for the multiple-budded 1-year-old corms. Other researchers (Mevel, 1983; Waithaka and Wanjao 1983) have found second-year corms to be very floriferous, which is in partial disagreement with our data (Fig. 2). These authors did not indicate whether their 2-year- 


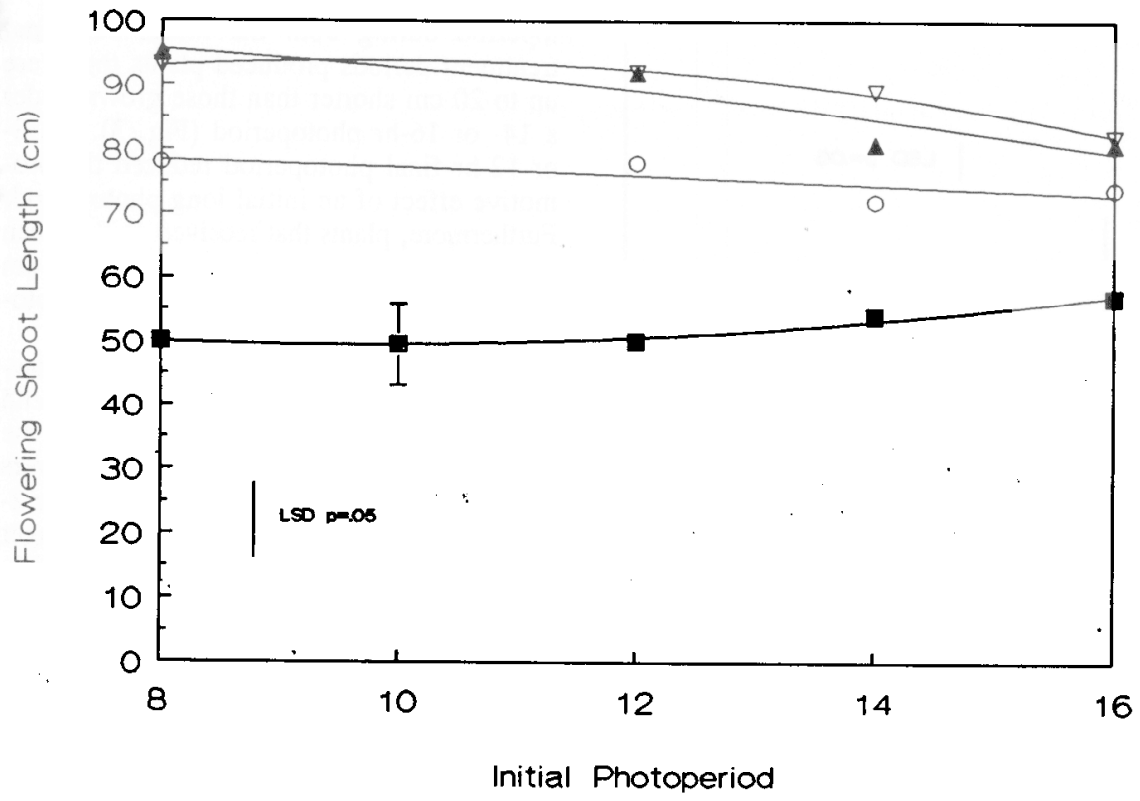

Fig. 3. Effect of initial (first 35 days after emergence) and final photoperiod (35 days after emergence until harvest) on the flowering shoot length of Liatris spicata Willd. Final photoperiods: $8 \mathrm{~h}(\varpi)$, length $=66.5-3.6 \mathrm{x}+0.18 \mathrm{x}^{2}, r^{2}=0.98 ; 12 \mathrm{hr}(\mathrm{o})$, length $=80.7-0.11 \mathrm{x}-0.02 \mathrm{x}^{2}, \vec{r}^{2}=$ $0.75 ; 14 \mathrm{hr}$ (A), length $=92.7+1.5 \mathrm{x}-0.14 \mathrm{x}^{2}, r^{2}=0.91 ; 16 \mathrm{hr}(\nabla)$ length $=65.1+5.9 \mathrm{x}-$ $0.3 \mathrm{x}^{2}, r^{2}=0.99$.

old corms were divided before forcing.

The number of shoots produced by the 2year-old corms grown under continuous 16$\mathrm{hr}$ photoperiod was almost twice the number produced under other treatments; however, the number of flowering shoots was not similarly increased (Fig. 2).

As photoperiod increases, shoot length increases (Durieux, 1978; Halevy, 1985; Shillo and Ha levy, 1976) (Fig. 3). But our results, as well as those of Durieux (1978) and Zieslin and Geller (1983), suggest that a morespeciflc combination of an initial SD (8 or $12 \mathrm{hr}$ ) and final LD (14 or $16 \mathrm{hr}$ ) after the effect of photoperiod as it relates to pot plant production of Liatris.

\section{Literature Cited}

Allard, H.A. and W.W. Garner. 1940. Further observations on the response of various species of plants to length of day. USDA Tech. Bul. 727.

Durieux, A.J.B. 1978. Bloci van Liatris. Lab. Bloembollenonderzoek, Lisse, Netherlands Praktijkmed. 47:1-15.

Halevy, A.H. 985. Gladiolus, p. 287-291. In: A.H. Halevy (ed.). Handbook of flowering. vol. III, CRC Press, Boca Raton, Fla.

Kofranek, A.M. 1980. Liatris. A. new crop for California. Flower and nursery report for commercial growers, summer 1980. Univ. of California Coop. Ext. p. 1-2.

Koziol, A.G., S.S. Salac, and J.B. Fitzgerald 1981. The effect of photoperiod and gibberellic acid on the growth and development of Liatris pycnostachya Mich. HortScience (Abstr.)

Mckay, M. E., B.J. Hesse, and J.C. Mulder. 1982. The influence of illumination levels of daylength extension on yield of winter-grown gladioli in Queensland. Scientia Hort. 17:277-288.

Mevel, A. 1983. Deux bulbeuses en vue: Allium et Liatris. L'Horticulture Francaise. No. 150:2124

Shillo, R. and A.H. Halevy. 1976. The effect of various environmental factors on flowering of gladiolus. H. Length of the day. Scientia Hort. 7:139-146.

Shillo, R., G. Valis, and A.H. Halevy. 1981. Promotion of flowering by photoperiodic lighting in winter-grown gladiolus planted at high densities. Scientia Hort. 14:367-375.

Waithaka, K. and L.W. Wanjao. 1983. The influence of corm source, age and size on the growth and flowering of Liatris spicata L. Acta Hort. 134:95-100

Zieslin, N. and Z. Geller. 1983. Studies with Liatris spicata Willd. 2. Effect of photoperiod on stem extension, flowering and gibberellin content. Ann. Bot. 52:855-859. 